\title{
Pemanfaatan Teknologi Informasi Digital Sebagai Media Informasi Gereja Santo Petrus Warak
}

\author{
Elisabeth Marsella ${ }^{1 *}$, Putri Nastiti ${ }^{2}$, Fransiska Hernina Puspitasari ${ }^{3}$ \\ ${ }^{1,2,3}$ Fakultas Teknologi Industri, Universitas Atma Jaya Yogyakarta, Indonesia \\ Email: ${ }^{1 *}$ elisabeth.marsella@uajy.ac.id, ${ }^{2}$ putri.nastiti@uajy.ac.id
}

(Naskah masuk: 07 Okt 2021, direvisi: 28 Okt 2021, diterima: 02 Nov 2021)

\begin{abstract}
Abstrak
Gereja dapat diartikan dalam dua hal, yaitu sebagai tempat beribadah umat Kristen dan juga suatu badan yang mengelola kegiatan-kegiatan umat Kristen, baik yang bersifat liturgis atau non-liturgis. Demikian pula dengan Gereja Santo Petrus Warak yang selalu mengagendakan kegiatan-kegiatan tersebut. Sejauh ini, Gereja tidak banyak memberitakan kegiatan atau perkembangan yang ada di Gereja karena beberapa keterbatasan, seperti media dan sumber daya. Akibatnya, banyak umat tidak tahu perkembangan gereja. Media yang sering digunakan Gereja untuk mendistribusikan informasi kegiatan adalah pengumuman, teks misa, tabloid, buletin, dan majalah Gereja. Kelemahan media ini adalah informasi terpisah-pisah sehingga dokumentasi kegiatan Gereja tidak terpusat. Hal itu dikarenakan proses pemberitaan dilakukan oleh banyak orang dan data tidak terpusat di Gereja. Melihat permasalahan tersebut, dibuatlah website yang dapat digunakan untuk menyebarkan informasi kepada umat Gereja. Pengurus Gereja dapat menginformasikan profil Gereja, kegiatan-kegiatan apa saja yang akan dilakukan di Gereja, dan formulir-formulir yang diperlukan untuk administrasi Gereja. Selain itu, website ini memungkinkan umat untuk berpartisipasi mengirimkan berita tentang kegiatan liturgis atau non-liturgis di wilayah masing-masing. Pembuatan fitur website ini bertujuan untuk menjawab tantangan terbatasnya sumber daya manusia untuk mengunggah berita secara berkala.
\end{abstract}

Kata kunci: website, informasi, berita, gereja

\section{Digital IT Utilization For Information Media Of Santo Petrus Church}

\begin{abstract}
A church can be defined into two functions: a place for Christians to worship and an institution that organizes the liturgic and non-liturgic activities. The same functions apply to the Church of Saint Peter Warak that regularly schedules the activities. However, the church does not publish the agenda and activities regularly held in the parish due to media and resources limitation. Therefore, the parishioners are not informed of the activities and development that the church has done. The church usually uses announcement in the mass, the mass text, and magazine as the publishing media. The weakness of these media is that the information is not integrated, which causes poor documentation. This happens because the information is shared by several people, and the data is not integrated. Concerning this problem, the authors initiate to design a website that can be used to share information with the parishioners. The administrators can share the profile of the church, the activities of parishioners, and the forms for church administration. Besides that, the website has a feature that allows the parishioners to participate in collecting the news about the liturgic and non-liturgic activities in each area. This feature aims to resolve the problems in the limitation of human resources that can provide the news regularly.
\end{abstract}

Keywords: website, information, news, church. 


\section{PENDAHULUAN}

Gereja dapat diartikan dalam dua hal, yaitu sebagai tempat beribadah umat Kristen dan juga suatu badan yang mengelola kegiatan-kegiatan umat Kristen. Gereja sebagai suatu organisasi tentu mencakup semua kegiatan yang diselenggarakan oleh umat Gereja. Kegiatan tersebut terbagi menjadi kategori liturgis dan non-liturgis. Kegiatan liturgis mencakup perayaan Ekaristi harian, perayaan Ekaristi mingguan, dan perayaan Ekaristi hari raya (Natal dan Paskah). Setiap tahunnya kegiatan tersebut tidak mengalami banyak perbedaan karena merupakan agenda rutin gereja. Berbeda halnya dengan kegiatan non-liturgis yang lebih sering dilakukan di luar kegiatan peribadatan. Sedangkan yang banyak menjadi perhatian Gereja adalah kegiatan nonliturgis seperti perkumpulan Pendampingan Iman Anak (PIA), Pendampingan Iman Remaja (PIR), Orang Muda Katolik (OMK), dan kegiatan komunitas Gereja lainnya.

Dengan banyaknya kegiatan umat, Gereja perlu menyediakan dan mengatur distribusi informasi kepada umat agar kegiatan dapat berjalan dengan lancar seperti jadwal kegiatan. Selain itu, Gereja juga perlu menginformasikan kegiatan-kegiatan gereja supaya umat mengetahui perkembangan gereja. Dalam setiap rangkaian kegiatan, Gereja juga perlu memberitakan hasil dari kegiatan tersebut. Hasil kegiatan dapat dibagikan dalam bentuk artikel maupun foto dan video.

Media yang sering digunakan Gereja untuk mendistribusikan informasi kegiatan adalah pengumuman, teks misa, tabloid, buletin, dan majalah Gereja. Kelemahan media ini adalah informasi terpisah-pisah sehingga dokumentasi kegiatan Gereja tidak terpusat. Hal itu dikarenakan proses pemberitaan dilakukan oleh banyak orang dan data tidak terpusat di Gereja.

Seiring dengan perkembangan teknologi, distribusi informasi mulai mengalami pergeseran cara. Gereja dalam perkembangannya juga mulai mengikuti alur perubahan tersebut. Distribusi informasi yang pada mulanya hanya melalui media cetak berpindah ke media digital, yang berupa media sosial dan website.

Istilah media sosial tersusun dari dua kata, yakni media dan sosial. Media diartikan sebagai alat komunikasi [1], [2]. Sedangkan kata sosial diartikan sebagai kenyataan sosial bahwa setiap individu melakukan aksi yang memberikan kontribusi kepada masyarakat. Pernyataan ini menegaskan bahwa pada kenyataannya, media dan semua perangkat lunak merupakan sosial atau dalam makna bahwa keduanya merupakan produk dari proses sosial [3]. Media sosial adalah media yang digunakan oleh konsumen untuk berbagi teks, gambar, suara, dan video informasi baik dengan orang lain maupun perusahaan [4]. Media sosial merupakan suatu sarana yang jika digunakan dengan baik bisa memperluas komunikasi kita dan memudahkan informasi kita dijangkau oleh banyak orang. Masyarakat luas dapat mengetahui informasi yang kita kirimkan dengan hanya bermodalkan telepon pintar dan internet.

Website merupakan kumpulan laman untuk menyampaikan suatu informasi yang di dalamnya bisa berisi gambar, suara, teks, atau gabungan dari ketiganya [5]. Website merupakan salah satu media untuk menyampaikan informasi kepada masyarakat luas dan bisa diakses dimanapun dan kapanpun [6], [7]. Website ini diperlukan oleh Gereja Warak sebagai sarana menyampaikan berbagai informasi kepada umat. Berdasarkan beberapa penelitian, website memberi beberapa keuntungan seperti meningkatkan ikatan antara organisasi dengan pengguna [8], mempercepat arus informasi [9], dan memberikan informasi yang pasti, lengkap, dan terkini [10].

Selama ini Gereja Warak hanya menggunakan media sosial Instagram dan Facebook. Akan tetapi, pengelolaan media sosial tersebut tidak masuk dalam struktur organisasi sehingga Gereja mengalami kesulitan untuk mengontrol keberlangsungan penggunaan media sosial. Karena tidak masuk dalam struktur organisasi, tanggung jawab untuk terus mengelola media sosial menjadi kurang. Misalnya, saat kontributor harus berpindah ke daerah lain, tidak ada penyerahterimaan tugas dan tanggung jawab pada pengurus lain.

Berdasarkan situasi di atas, maka diadakanlah pengabdian ini. Pengabdian ini disusun untuk memberikan pendampingan pembuatan media digital bagi Gereja Warak melalui website gereja. Aktivitas yang akan dilakukan adalah membuatkan website gereja. Dengan website tersebut, umat gereja khususnya para ketua lingkungan dapat berpartisipasi dalam pendistribusian informasi kegiatan gereja, melalui konten baik berupa foto maupun video.

Melalui pendampingan ini diharapkan umat dapat terbantu dalam mengurus administrasi gereja dan umat mendapatkan satu sumber informasi. Misalnya, gereja dapat menyediakan formulir-formulir administrasi di situs web, sehingga umat dapat mengunduh formulir tersebut saat dibutuhkan. Selain itu, OMK dapat mengembangkan diri dalam dokumentasi kegiatan gereja berupa tulisan, gambar ataupun video. Selain itu, informasi mengenai rencana kegiatan dan laporan hasil kegiatan dapat tersalurkan kepada umat dengan baik. Dengan dokumentasi dan penyampaian informasi yang baik, Paroki Santo Petrus Warak dapat membangun kredibilitas dan profesionalisme organisasi.

Beberapa penelitian maupun pengabdian sebelumnya yang berkaitan dengan pemanfaatan teknologi informasi sebagai media informasi untuk tempat ibadah, juga dilakukan oleh [11], [12] yaitu pembuatan website sebagai media komunikasi untuk GKI Sinode Jawa Tengah, serta pemberdayaan pemuda sebagai tim multimedia dan teknologi informasi untuk Gereja Betania di Kepulauan Sangihe. 


\section{METODE, TAHAPAN, DAN LUARAN}

Menurut Roger S Pressman, terdapat tiga tahapan dalam pengembangan prototype [13] yaitu mendengarkan pengguna akhir, membangun dan memperbaiki prototipe, dan menguji coba prototype.

Pengabdian masyarakat ini akan mengadopsi tahapan pengembangan prototype Pressman sebagai berikut:

1. Mendengarkan pengguna akhir sistem

Pada tahap ini dilakukan pengumpulan kebutuhan dari sistem dengan cara mendengar keluhan dari pengguna. Untuk membuat sistem sesuai dengan kebutuhan, maka harus diketahui terlebih dahulu, bagaimana sistem yang sedang berjalan untuk kemudian mengetahui masalah yang terjadi.

Dalam pengabdian ini, kebutuhan Gereja didapatkan dengan wawancara dan diskusi dengan pastur kepala dan pengurus gereja. Data-data yang dikumpulkan seperti profil gereja, jadwal misa harian, kontak, acara-acara gereja yang telah diselenggarakan di gereja tersebut, dan lain-lain. Selain itu, wawancara ini dilakukan untuk mengetahui kebutuhan atau permintaan tertentu dari pihak gereja yang dapat jadi masukan untuk pembuatan website nantinya. Data yang dikumpulkan ini nantinya akan digunakan untuk konten website.

2. Merancang dan membuat prototype

Pada tahap ini dilakukan perancangan dan pembuatan prototype sistem yang disesuaikan dengan kebutuhan Gereja.

3. Uji coba

Pada tahap ini prototype dari sistem diuji coba oleh pelanggan atau pengguna. Kemudian dilakukan evaluasi kekurangan dari kebutuhan pelanggan. Pengembangan kemudian kembali mendengarkan keluhan dari pelanggan untuk memperbaiki prototype yang ada.

4. Hosting

Web hosting merupakan ruangan dalam harddisk untuk menyimpan berbagai data, file, gambar dan lain sebagainya yang akan ditampilkan pada website. Web Hosting pada pengabdian ini dilakukan dengan menyewa domain kepada penyedia jasa hosting.

Pelaksanaan kegiatan Pengabdian Masyarakat ini dibagi kedalam 3 tahap yaitu tahap awal, tahap tengah dan tahap akhir. Tabel 1 menampilkan rincian kegiatan dan luarannya.

Tabel 1. Tahapan dan Luaran Kegiatan

\begin{tabular}{lll}
\hline No & $\begin{array}{l}\text { Kegiatan } \\
\text { Tahap Awal }\end{array}$ & Luaran \\
\hline 1 & $\begin{array}{l}\text { Menyiapkan rencana } \\
\text { kerja secara detail }\end{array}$ & $\begin{array}{l}\text { Dokumen rencana kerja } \\
\text { Dokumen materi }\end{array}$ \\
2 & $\begin{array}{l}\text { Memetakan } \\
\text { kebutuhan mitra }\end{array}$ & $\begin{array}{l}\text { informasi yang } \\
\text { didapatkan dari mitra }\end{array}$ \\
\hline
\end{tabular}

DOI: $10.34148 /$ komatika.v1i2.410

\begin{tabular}{|c|c|c|}
\hline & Tahap Tengah & \\
\hline 3 & Membuat website & $\begin{array}{l}\text { Website } \\
\text { http://parokiwarak.org/ }\end{array}$ \\
\hline 4 & $\begin{array}{l}\text { Melakukan uji coba } \\
\text { website }\end{array}$ & Hasil uji coba website \\
\hline 5 & $\begin{array}{l}\text { Memberikan } \\
\text { pelatihan ke mitra } \\
\text { tentang penggunaan } \\
\text { website }\end{array}$ & $\begin{array}{l}\text { Pengetahuan mengenai } \\
\text { penggunaan website }\end{array}$ \\
\hline & Tahap Akhir & \\
\hline 6 & $\begin{array}{l}\text { Penyusunan laporan } \\
\text { akhir }\end{array}$ & $\begin{array}{l}\text { Laporan final } \\
\text { Pengabdian Masyarakat }\end{array}$ \\
\hline 7 & Membuat publikasi & Artikel publikasi \\
\hline
\end{tabular}

\section{HASIL DAN PEMBAHASAN}

Seperti yang sudah dituliskan pada metode, kegiatan pengabdian masyarakat ini dikelompokan menjadi tiga fase, yaitu persiapan, pelaksanaan, dan pelaporan. Pada fase persiapan yang dilakukan adalah menggali kebutuhan data apa saja yang ingin ditampilkan dalam website dan media sosial yang akan dibuat, kemudian menyiapkan pembuatan website dan pembuatan akun media sosial. Paroki Warak sebelumnya sudah memiliki website yang digunakan sebagai sumber informasi bagi umat. Namun pada proses pengembangannya tidak berjalan dengan baik dikarenakan kurang sumber daya manusia dalam pengelolaan situs web. Selain situs web, media sosial juga merupakan sarana bagi Gereja sebagai media informasi digital. Kebutuhan Gereja Paroki Warak dalam pembuatan situs web ini, tidak hanya sebagai sumber informasi satu arah saja, tetapi Gereja mengharapkan adanya keterlibatan umat dalam berbagi informasi.

Pada tahapan pelaksanaan yang dilakukan adalah implementasi website sesuai dengan kebutuhan Gereja Paroki Warak. Alamat situs web yang kami bangun untuk Gereja Paroki Warak adalah www.parokiwarak.org. Semua informasi yang berkaitan dengan Gereja Warak dimasukkan ke dalam konten profil website. Gambar 1 merupakan tampilan website Gereja Paroki Warak, terdiri dari pilihan menu beranda, profil, komisi, unduh formulir, kontak, suara umat, dan admin. 


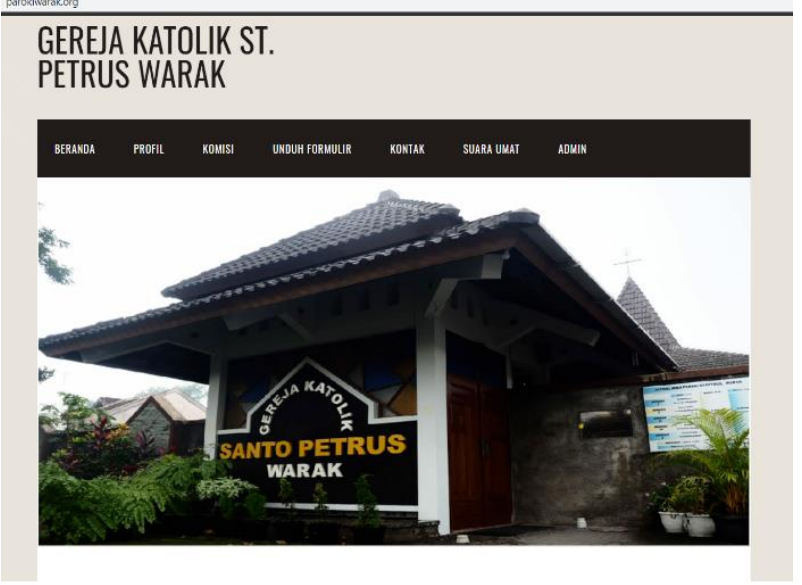

Gambar 1. Tampilan website Gereja Paroki Warak

Gambar 1 dan 2 merupakan tampilan halaman beranda. Halaman beranda berisi artikel-artikel terbaru yang dimuat dalam portal website. Artikel-artikel tersebut memuat kegiatan-kegiatan yang telah dilaksanakan di lingkungan gereja.

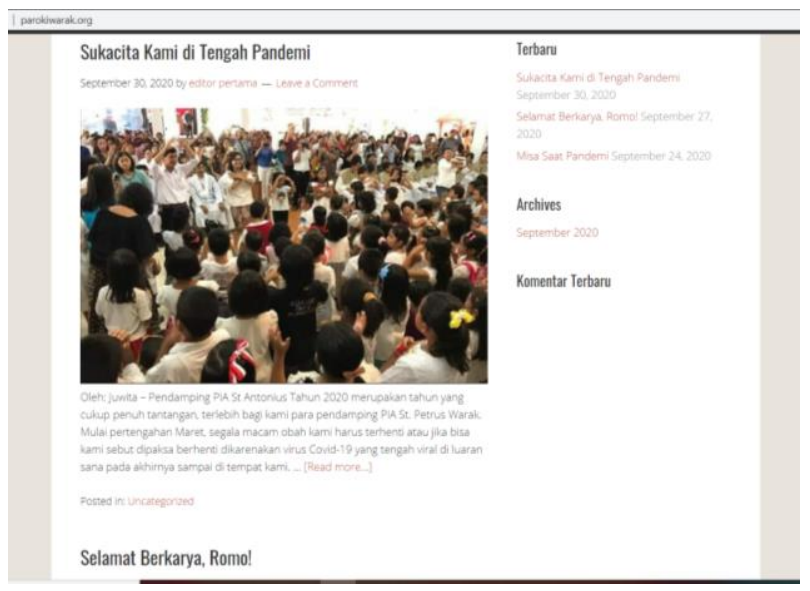

Gambar 2. Halaman Beranda Gereja Paroki Warak

Gambar 3 merupakan halaman profil website. Halaman profil terdiri dari dua sub menu yaitu halaman sejarah dan halaman visi misi. Di halam sini, pengunjung website dapat tahu sejarah pada paroki Gereja Warak dari awal berdiri sampai sekarang. Selain itu juga mengetahui visi dan misi yang dijadikan pedoman dalam pelayanan di Gereja Warak.

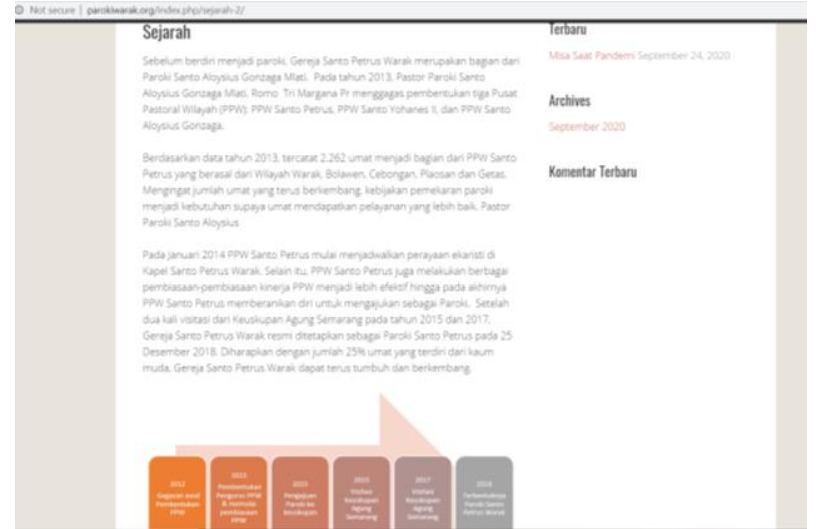

Gambar 3. Halaman Profil Paroki Warak

Menu selanjutnya adalah halaman Komisi yang dapat dilihat pada Gambar 4. Pada halaman ini, pengunjung website dapat mengakses bidang-bidang apa saja yang dimiliki oleh Gereja Warak atau, di sini, disebut dengan komisi. Terdapat beberapa sub-menu pada menu ini, yaitu bidang liturgi dan peribadatan, bidang pewartaan, bidang pelayanan kemasyarakatan, bidang paguyuban dan tata organisasi, bidang rumah tangga, serta bidang penelitian dan pengembangan. Jika diklik sub-menu tersebut, maka kursor akan langsung mengarah langsung ke masing-masing bidang dimana setiap bidang memiliki tim kerja.
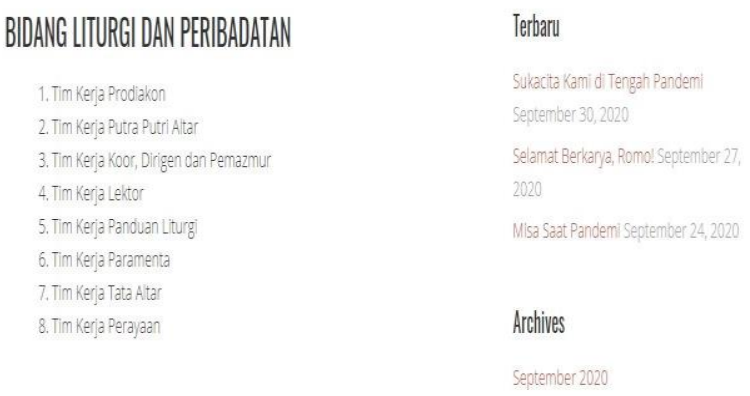

Komentar Terbaru

Gambar 4. Halaman Komisi

Pada website ini, Gereja Warak juga menyediakan menu Unduh Formulir yang ditunjukkan pada Gambar 5. Menu ini digunakan oleh pihak Gereja untuk mengupload formulirformulir penting yang dibutuhkan umat, semisal untuk melaporkan kematian, mendaftar komuni pertama, dan lainlain. Menu ini dibuat agar umat tidak perlu harus datang ke gereja untuk mendapatkan formulir, tetapi cukup membuka website dan mengunduh formulir di sana. 


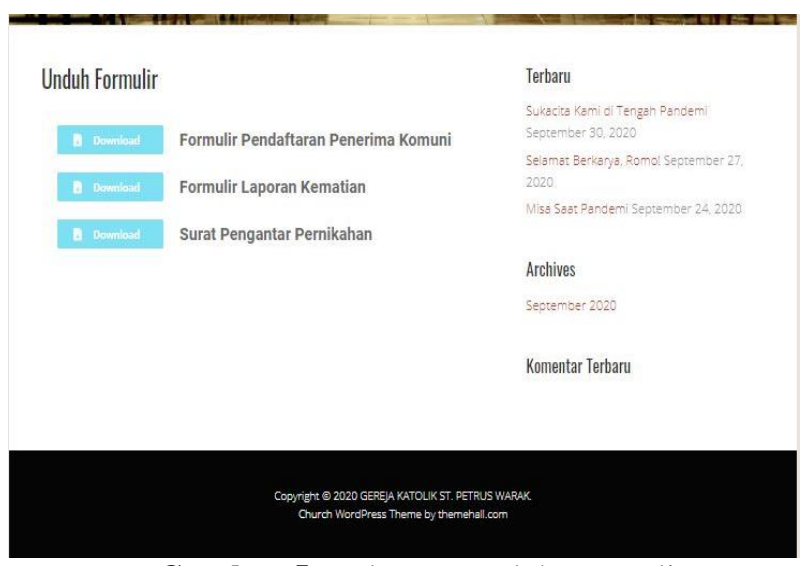

Gambar 5. Halaman Unduh Formulir

Halaman selanjutnya adalah Kontak yang ditunjukkan pada Gambar 6. Halaman ini menampilkan kontak kesekretariatan paroki Gereja Warak. Selain itu, di halaman ini menampilkan informasi jam kerja kesekretariatan dan lokasi gereja menggunakan Google Maps.

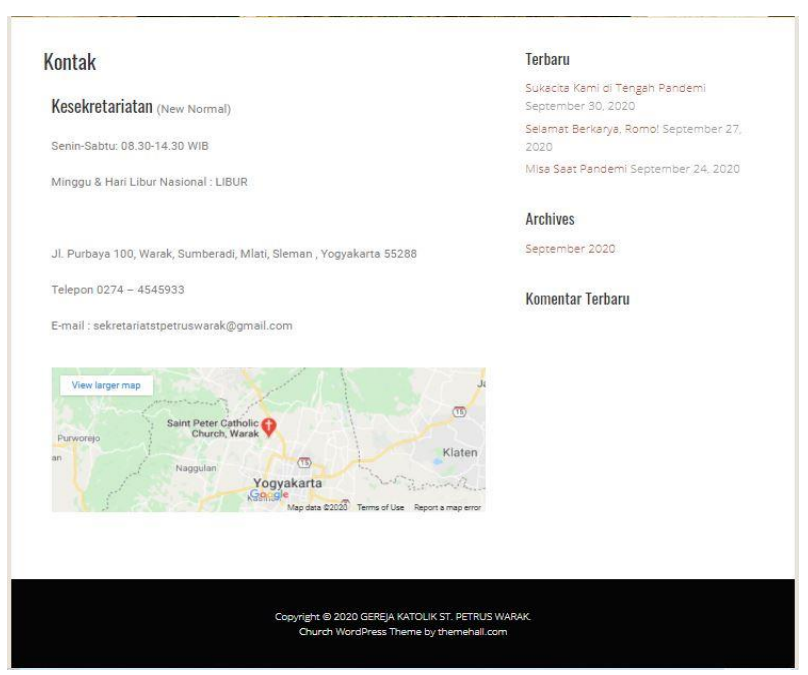

Gambar 6. Halaman Kontak

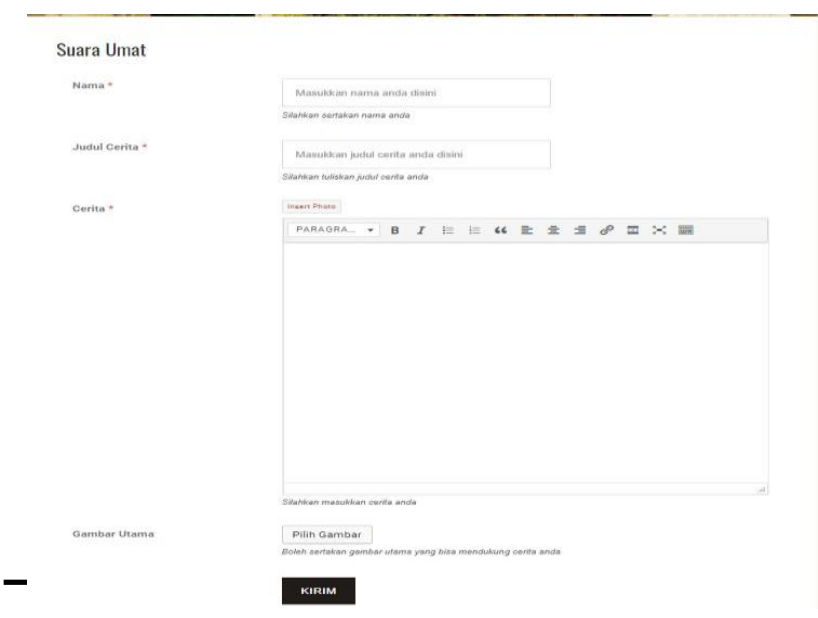

DOI: $10.34148 /$ komatika.v1i2.410

\section{Gambar 7. Halaman Suara Umat}

Halaman suara umat yang terdapat pada Gambar 7 merupakan salah satu yang paling dibutuhkan oleh Gereja Paroki Warak. Halaman ini merupakan bentuk upaya Gereja dalam rangka menarik partisipasi umat untuk saling berbagi informasi. Halaman Suara Umat memberi fleksibilitas kepada umat untuk mengirimkan berita melalui ponsel pintar mereka. Misalnya, ketika umat sedang mengikuti acara Gereja, mereka dapat dengan mudah mengunggah foto kegiatan beserta narasi kegiatan tersebut. Dengan halaman ini, umat dapat membagikan berita dari wilayah masingmasing. Umat yang akan mengirimkan berita dapat menuliskan di halaman suara umat. Umat juga dapat menambahkan gambar atau video pada berita yang akan dikumpulkan.

Setelah umat mengirimkan berita, admin atau editor dapat memeriksa kiriman umat tersebut pada dashboard admin. Jika diperlukan, editor dapat memperbaiki tulisan umat langsung pada halaman sebelum berita ditampilkan. Apabila berita yang dikirim umat tidak layak untuk ditampilkan, editor dapat menolak tulisan umat tersebut. Dengan demikian, editor juga memiliki fleksibilitas dalam memeriksa artikel dari umat. Hal ini ditampilkan pada Gambar 8, 9, 10 dan 11.

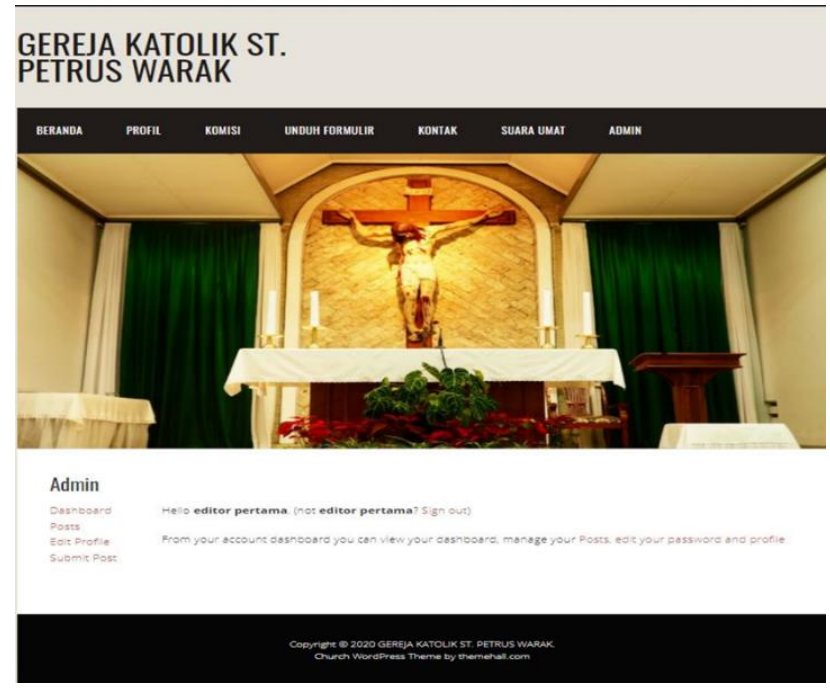

Gambar 8. Halaman Admin (Dashboard) 


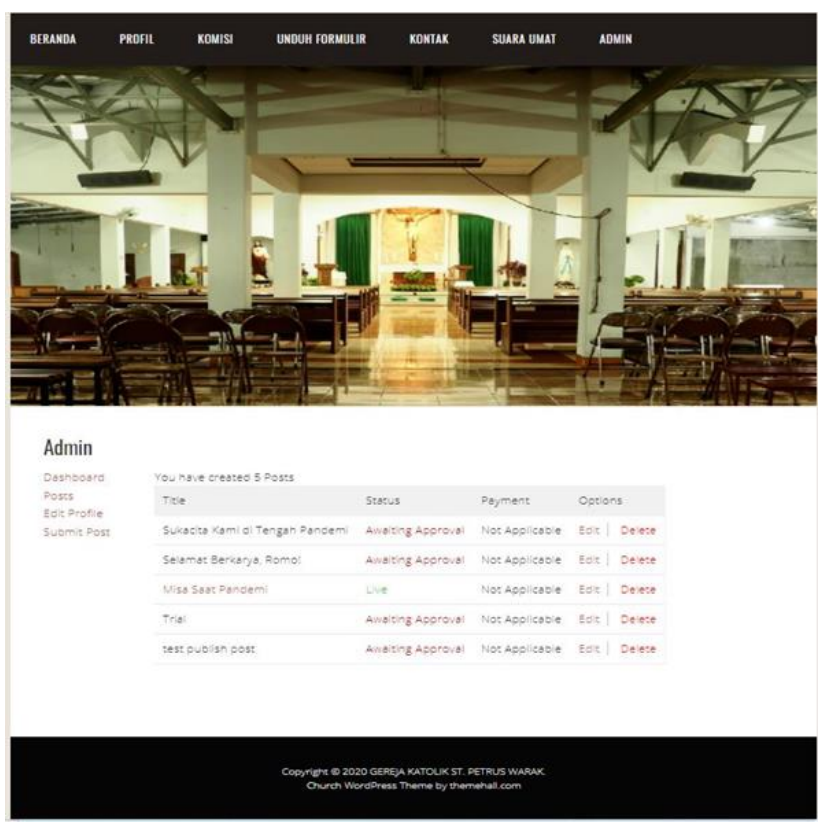

Gambar 9. Halaman Posts

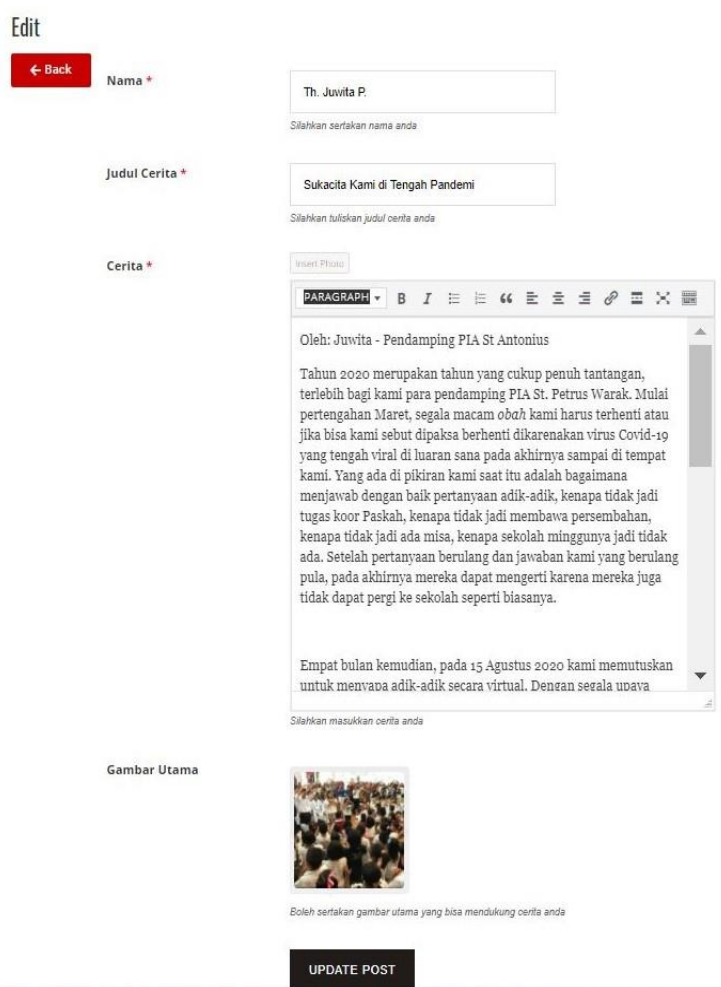

Gambar 10. Halaman Edit Tulisan

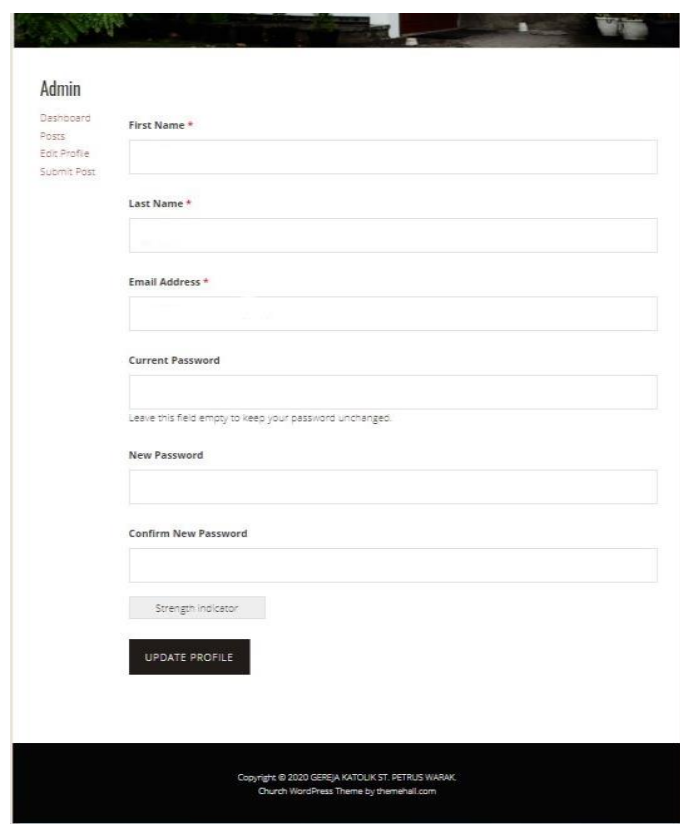

Gambar 11. Halaman Edit Profile

Seperti yang diharapkan oleh Pengurus Paroki, situs web ini memotivasi umat untuk membagikan berita dari wilayah mereka. Hal ini tentu memudahkan Gereja dalam mendapatkan informasi terbaru sekaligus menyebarkan informasi tentang perkembangan setiap wilayah.

\section{KESIMPULAN}

Kegiatan pengabdian pada masyarakat ini telah selesai dilaksanakan dan sesuai dengan tujuan awal kegiatan. Pembuatan website ini bertujuan untuk memberikan pendampingan pembuatan media digital yang berupa website. Dengan adanya website tersebut, umat dapat berpartisipasi dalam penyampaian informasi kegiatan gereja, baik berupa tulisan, foto, maupun video. Dengan adanya keterlibatan seluruh umat, informasi kepada umat menjadi lebih merata.

Pengabdian dapat dikembangkan lebih jauh lagi kedepannya, yaitu dengan pembuatan sistem pendataan umat yang terintegrasi dengan website Gereja Santo Petrus Warak. Sebagai gambaran, umat dapat mendaftar komuni pertama atau pembaptisan melalui website. Umat hanya perlu berkunjung ke website Gereja, memasukkan data yang diperlukan, dan menunggu verifikasi dari Gereja. Dengan cara ini, pendataan dan arsip Gereja akan lebih mudah, rapi, dan lengkap

\section{UCAPAN TERIMA KASIH}

Ucapan terima kasih penulis sampaikan kepada Lembaga Penelitian dan Pengabdian Universitas Atma Jaya 
Yogyakarta yang telah menjadi sponsor dalam pengabdian ini.

\section{REFERENSI}

[1] D. Laughey, Themes in media theory. New York: Open University Press, 2007.

[2] D. McQuail, Teori komunikasi massa. Jakarta: Penerbit Erlangga, 2003.

[3] C. Fuchs, Social media: A critical introduction. Los Angeles: Sage Publications Ltd., 2014.

[4] P. Kotler and K. L. Keller, Marketing Management, 15 th. New Jersey: Pearson Pretice Hall, Inc, 2016.

[5] R. Abdulloh, Web Programming is Easy. Jakarta: PT Elex Media Komputindo, 2015.

[6] F. I. Maulana and C. Huda, "Design website portal information crime-prone location using the concept of crowdsourcing," J. Electr. Eng. Mechatronics, Comput. Sci., vol. 3, pp. 25-32, 2020.

[7] Subandi, Syahidi, A. A. and A. N. Asyikin, "Strategic planning and implementation of academic information system (AIS) based on website with D\&M model approach," 2018.

[8] S. Molinillo, R. Anaya-Sánchez, and F. Liébana-
Cabanillas, "Analyzing the effect of social support and community factors on customer engagement and its impact on loyalty behaviors toward social commerce websites," Comput. Human Behav., vol. 108, 2020.

[9] Z. Lu, R. Han, and J. Duan, "Analyzing th effect of website information flow on realistic human flow using intelligent decision models," Knowledge-Based Syst., vol. 23, pp. 40-47, 2010.

[10] F. Salehi, B. Abdollahbeigi, A. C. Langroudi, and F. Salehi, "The Impact of Website Information Convenience on E-commerce Success of Companies," Procedia - Soc. Behav. Sci., vol. 57, pp. 381-387, Oct. 2012, doi: 10.1016/j.sbspro.2012.09.1201.

[11] D. Tuwohingide, C. Koloay, A. Papuas, and C. Technology, "Pemberdayaan Pemuda Gereja Sebagai Tim Multimedia Dan Teknologi Informasi Information," pp. 39-43, 2019.

[12] B. Susanto, "Pemanfaatan Teknologi Web Sebagai Media Komunikasi Gki Sinode Wilayah Jawa Tengah," no. January, 2017.

[13] I. Sommerville, Software Engineering (Rekayasa Perangkat Lunak. Jakarta: Penerbit Erlangga, 2011. 